\title{
Talent management in the process of employee retention in Shared Services Centers
}

\section{Zarządzanie talentami w procesie utrzymania pracowników w centrum usług wspólnych}

\author{
Julian Dąbrowski \\ Poznań University of Economics and Business, e-mail: julian.dabrowski@gmail.com; ORCID: 0000-0002-5643-1809
}

\begin{abstract}
The aim of the article is to specify how Shared Services Centers (SSC), can use talent management practices to retain employees. For this purpose, theoretical studies including contemporary scientific literature as well as empirical studies covering a survey of 249 respondents who were current employees of Shared Service Centers located in the city of Poznań were carried out. The subjective scope of the study has been narrowed down to minimize the risk of interpretational error resulting potentially from differences in the industry context. The author places talent management in the process of employee retention, and then discusses the results of empirical research. He defines the perception of talent management concept by employees, and also indicates statistically significant differences that may affect the shaping of intra-organizational processes.

Keywords: talent management, Shared Services Center, employee retention.
\end{abstract}

\begin{abstract}
Streszczenie
Celem artykułu jest dookreślenie tego, w jaki sposób organizacje zatrudniające pracowników do wykonywania powtarzalnej pracy mogą skorzystać z zarządzania talentami, aby skuteczniej ich utrzymywać. Przeprowadzono w tym zakresie badania teoretyczne obejmujące współczesną literaturę naukową, a także empiryczne obejmujące badanie ankietowe przeprowadzone na grupie 249 respondentów będących aktualnymi pracownikami centrów usług wspólnych ulokowanych na terenie miasta Poznania. Zakres podmiotowy badania został zawężony w celu zminimalizowania ryzyka błędu interpretacyjnego wynikającego potencjalnie z różnic w kontekście branżowym. Autor wpierw umiejscawia zarządzanie talentami w procesie utrzymania pracowników, a następnie omawia wyniki badań empirycznych. Wskazuje sposób postrzegania tej koncepcji zarządzania talentami przez pracowników, a także zaznacza statystycznie istotne różnice, które mogą wpływać na kształtowanie procesów wewnątrzorganizacyjnych.
\end{abstract}

Słowa kluczowe: zarządzanie talentami, centrum usług wspólnych, utrzymanie pracowników. 


\section{Introduction}

Talent management has gone beyond the interest of business practitioners and is increasingly reflected in ongoing research [Collings et al. 2015; Gallardo-Gallardo et al. 2017]. The popularity of this concept is influenced by the results of empirical research indicating the consequences of its application by enterprises that obtain better business results [Almaaitah et al. 2015; Altınöz et al. 2013; Joyce, Slocum 2012; Kohtamäki et al. 2012; Muntean 2014; O'Connor et al. 2006; Sparrow, Makram 2015].

Table 1. Examples of research in a particular context

\begin{tabular}{|l|l|}
\hline \multicolumn{1}{|c|}{ Authors } & \multicolumn{1}{c|}{ Research context } \\
\hline [Valverde, Scullion, Ryan 2013] & $\begin{array}{l}\text { Spanish small and medium } \\
\text { enterprises }\end{array}$ \\
\hline [Kim, Mclean 2012] & Global enterprises \\
\hline [Ready, Hill, Conger 2008] & Emerging markets \\
\hline [Solberg 2015] & Football clubs \\
\hline [Almaaitah, Harada, Bin 2015] & Mobile networks \\
\hline [Lepori, Seeber, Bonaccorsi 2015] & Higher education \\
\hline [Thunnissen, Van Arensbergen 2015] & Dutch Universities \\
\hline [Singh, Sharma 2015] & UAE enterprises \\
\hline [Ingram 2016] & Art and culture \\
\hline [Ingram, Glod 2016] & Healthcare enterprises \\
\hline
\end{tabular}

Source: based on own research.

The variety and lack of cohesion between various definitions of talent has been pointed out by researchers for many years [Howe et al. 1998, p. 399] and there is still no uniform solution [Collings et al. 2015; Lewis and Heckman 2006; McDonnell et al. 2017]. This results in difficulties in clearly defining also the role of talent management, and thus related to defining its impact on the functioning of the organization. However, what is more often undertaken is research aimed at systematizing knowledge in this area, so as to formulate the theoretical and practical assumptions needed both for researchers and representatives of business organizations. The article includes both theoretical and practical considerations that justify the use of talent management in order to more effectively retain employees in Shared Services Centers. Choosing this precise group of subjects was justified by a trend of analyzing talent management in the context of different business as shown in Table 1 below (Tab. 1).

\section{Conclusions from theoretical research - reasons for introducing talent management in shared service centers}

There are different concepts of talent as well as talent management. The dispute about their meaning should be resolved, according to the author, by taking into account the interpretation of the functional concept - that is, by setting a goal which, with the help of the practical application of these concepts, is to be achieved. This assumption results from the origin of these concepts within the management sciences where science tries to describe the organizational practice, so as to create the foundations for its further development [Schulz, Brenner 2010, p. 217]. The initial interest in these concepts in terms of the subject had its source in empiricism. The most important conclusions in determining the essence of the concept of talent management are presented in section 2.1, so to allow further discussion about its impact on the retention of employees. Section 2.2. includes defining the specificity of the operation of Shared Services Centers and, thanks to that, enables conclusions to be drawn regarding the reasons for which talent management solutions should be introduced in such organizations.

\subsection{The essence of talent management}

Objectives that are achieved by talent management according to the declarations of the organizations applying them remain without major changes over the years [Dąbrowski Skowron-Mielnik 2016, p. 267]. They are primarily related to ensuring and maintaining the necessary competences in the organization to achieve operational and strategic objectives (Figure 1).

Five of the first six main goals according to the above-mentioned research include actions aimed at maintaining employees (both those defined by the organization as talents and those who do not meet this definition) and securing with them the necessary competences in the organization of competences.

The author personally, for the purposes of this article, adopts the definition of talent management as: a set of activities carried out by the organization in relation to people defined as talents, in order to acquire or retain them, so that they contribute to achieving the intended organizational goals. Such a definition stems from the results of the conducted research as part of the completed dissertation, as well as from the conclusions drawn from previous publications [Dąbrowski 2016; 2015]. The process of deriving definitions is not the aim of this article, hence the author refers to other epistemological studies.

\subsection{Talent management in the reality of functioning of Shared Services Centers}

Shared Service Centers (also referred to as SSC in this article) are business entities that arise to maximize the profits of related companies, which may occur by increasing profits, reducing costs or increasing the organization's flexibility [Skowron -Mielnik 2012, p. 12]. Their characteristic features, appearing most often in literature [Schulz, Brenner 2010, pp. 213-214], are:

1) arising by combining processes between organizational units,

2) focus on the implementation of services supporting the main business objectives of other organizations,

3) the purpose of existence which is to reduce the costs of the mother company,

4) implementation of activities focused on the internal client,

5) legal subjectivity, fully related to other organizations,

6) being subject to market pricing rights. 


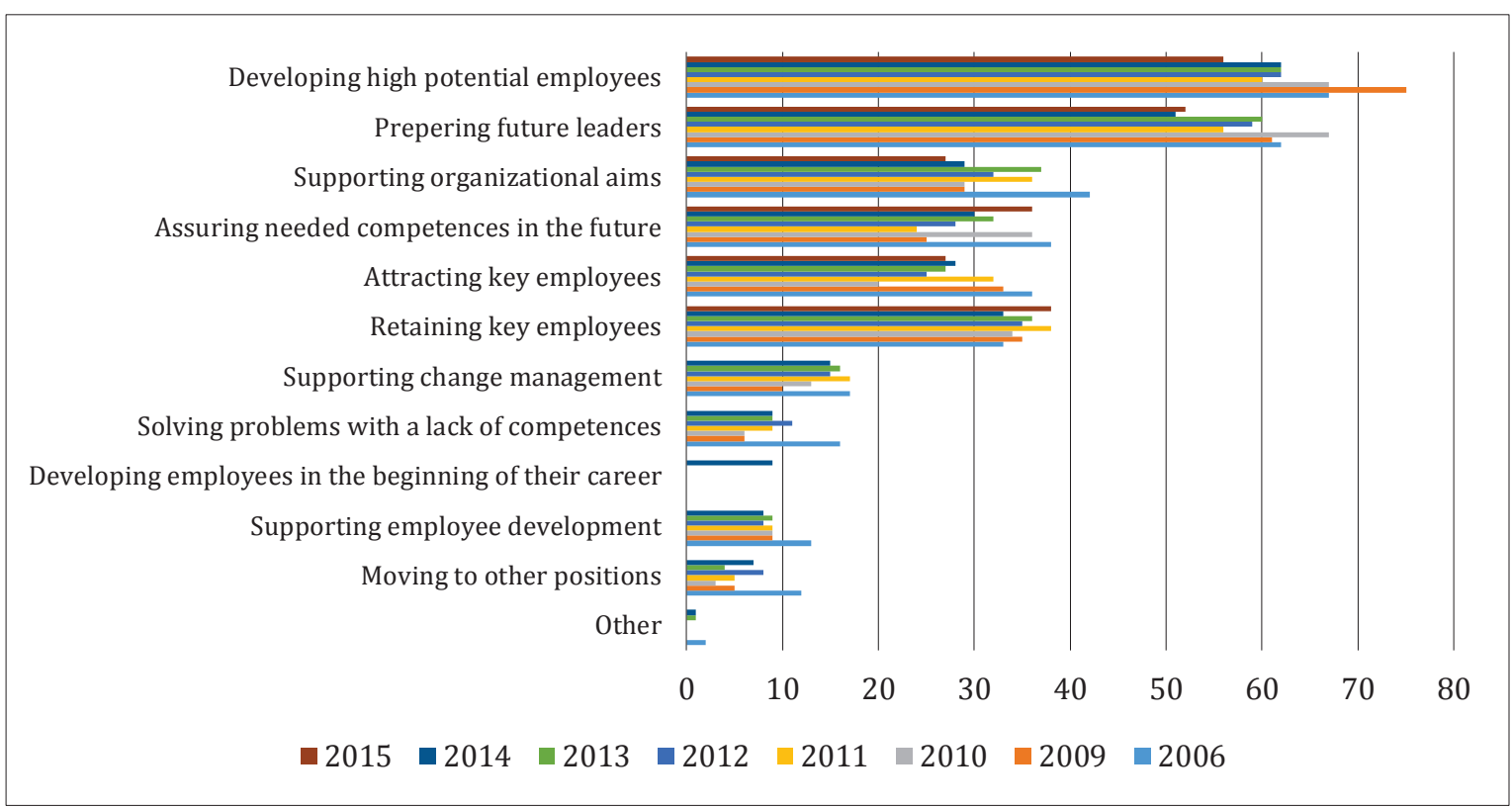

Figure 1. The most important goals realized through talent management

Source: own elaboration based on [CIPD 2015; 2014; 2013; 2011; 2010; 2009; 2006].

Shared Service Centers allow reducing costs both in a revolutionary way (at the same time limiting the number of employees needed and resources needed to implement processes), and evolutionally (when the transferred processes are constantly improved) which is required by the market conditions of SSC operations. It allows achieving economies of scale and significant savings [Szulaski 2012, p. 110]. This can be achieved through stronger decentralization, reduction of the scope of specialization, flattening of the hierarchy and simplification of coordination, and this requires the use of the competence of employees who will be able to take responsibility for their part of the process. On the one hand, SSC organizations in the future (and some now) will carry out activities related to the performance of repetitive work. On the other hand, there is a clear tendency to transform them into knowledge management and process control centers [Ernst \& Young 2013, pp. 5-8 ]. In order to develop centers of shared services from the level of "administrative manufactories" to the organizations referred to in the cited publication of Ernst \& Young as the second generation, it is necessary to create an environment in which people:

- want to question the status quo as part of the entire organization's operation,

- are able to think about their work in a strategic way,

- know how to involve themselves and others in the change process,

- are able to take full responsibility for the tasks performed,

- want to acquire competences to develop themselves as experts,

- and at the same time have knowledge of the processes being carried out.

The development of each of these competences is particularly difficult in the face of relatively high turnover in organizations of this type, which according to the largest industry organization [ABSL 2017a, p. 38] is over 15\% for 37\% of them.

One of the answers to the problem related to the maintenance and development of competences within the SSC is the introduction of talent management, which by its very nature pursues exactly the objectives that respond to the challenges of contemporary shared service centers operating in Poland.

\section{Conclusions from empirical research - how talent management may influence the retention of Shared Services Centers' employees}

An empirical study using an online questionnaire was conducted on a sample of 249 people who were current employees of Shared Services Centers operating in Poznań. This represents $3.2 \%$ of people employed in Wielkopolska in this industry [ABSL 2017b] and 4\% employed in Poznań (according to information obtained from the Department of Economic Activity of the Poznań City Hall). Due to the size of the sample, the conclusions described below cannot be generalized, but they can be an important reference point for further research or implementation.

\subsection{Research methodology}

The survey was disseminated using social networking sites (linkedin.com, goldenline.pl, facebook.com). The variables describing to enable statistically significant differences between respondents to be shown were age, years of employment in the current enterprise, the number of previous jobs, the number of foreign languages mastered at communicative level (at least B2), membership in the personal department, and 
a declaration whether the respondent believes that he/she should be defined in his/her current organization as a talent. The structure of respondents is presented in Table 2.

Table 2. Respondents' structure

\begin{tabular}{|l|c|}
\hline & Respondents' structure - gender \\
\hline \multicolumn{1}{|c|}{ Gender } & Number of answers \\
\hline Female & 175 \\
\hline Male & 74 \\
\hline & Respondents' structure - age \\
\hline \multicolumn{1}{|c|}{ Age } & Number of answers \\
\hline$<20$ & 144 \\
\hline $20-30$ & 93 \\
\hline $31-40$ & 11 \\
\hline $41-50$ & 9 \\
\hline
\end{tabular}

\begin{tabular}{|l|l|l|l|l|l|l|l|l|l|l|l|l|l|l|}
\hline \multicolumn{10}{|c|}{ Respondents' structure - employment in previous SSC } \\
\hline $\begin{array}{l}\text { Number of previous SSC in which } \\
\text { respondents worked }\end{array}$ & 0 & 1 & 2 & 3 & 4 & 5 \\
\hline Answers & 11 & 110 & 79 & 31 & 28 & 1 \\
\hline Respondents' structure - length of employment \\
\hline $\begin{array}{l}\text { Years of } \\
\text { employment } \\
\text { in current SSC }\end{array}$ & 1 & 2 & 3 & 4 & 5 & 6 & 7 & 8 & 9 & 10 & 11 & 12 \\
\hline Answers & 55 & 68 & 51 & 28 & 9 & 19 & 2 & 1 & 4 & 7 & 2 & 3 \\
\hline
\end{tabular}

Source: own study based on the results of the research.

The conclusions from the study were subjected to deductive reasoning and made it possible to formulate conclusions regarding the possibilities of using the talent management concept for the needs of employees of Shared Services Centers.

\subsection{Perspective of employees on the functioning of talent management in their organizations}

In order to determine the ratio of study participants to the implementation of talent management in the organization in which they work, they were asked to mark the answer on the Likert scale, where individual grades corresponded to a higher level of satisfaction, as shown in Table 3.

Dividing the scale into positive (4 and 5), neutral (3) and negative ( 1 and 2 ) feelings, the result is presented in Figure 2.

In the study it was considered statistically significant ( $p$-value $=0.01291$ ) that men more often indicated neutral responses and women negative ones. This result may suggest that for men the lack of talent management is much more ambivalent than for women. Negative feelings were strongly related to the fact that there was no talent management in the organization. Lack of belonging to a group of talents (despite the existence of such a group in a given SSC) caused much less negative feelings than lack of talent management in general. The justification for this may be a psychological mechanism of belittling the value of good, to which we have no access. An analysis of this question may indicate that the very fact of implementing talent management has a positive effect on the increase of employees' involvement - regardless of whether they will be its participants or not. It is worth paying attention to the fact that some people have negative or neutral feelings towards their participation in talent management. The justification for this may be, among others, their additional burden on development tasks. What is important, therefore, improperly prepared

Table 3. Satisfaction with talent management from the perspective of current employees

\begin{tabular}{|l|c|c|c|c|c|}
\hline \multicolumn{1}{|c|}{ Likert scale } & $\mathbf{1}$ & $\mathbf{2}$ & $\mathbf{3}$ & $\mathbf{4}$ & $\mathbf{5}$ \\
\hline $\begin{array}{l}\text { Yes, I'm in } \\
\text { a talent pool }\end{array}$ & $\begin{array}{c}\text { I am } \\
\text { frustrated }\end{array}$ & $\begin{array}{c}\text { I don't } \\
\text { feel good }\end{array}$ & I am ok & $\begin{array}{c}\text { I am happy } \\
\text { with that }\end{array}$ & Great! \\
\hline $\begin{array}{l}\text { No, I'm not in } \\
\text { a talent pool } \\
\text { but TM is in } \\
\text { my SSC }\end{array}$ & 8 & 4 & 53 & 16 & 14 \\
\hline $\begin{array}{l}\text { Lack of TM in } \\
\text { my SSC }\end{array}$ & 19 & 29 & 69 & 9 & 8 \\
\hline
\end{tabular}

Source: own study based on the results of the research.

or implemented talent management and its monitoring can bring more losses for the talents and organizations themselves than for those who have not been qualified by the talent group.

In the further part of the survey respondents pointed to who is called talent in their organization. The responses were grouped using the author's distribution of the definition of talent. The individual fields indicate the number of indications corresponding to each type of definition. 105 respondents answered in the form of an open statement. The sum of indications in the figure is, however, higher, because some respondents indicated multipoint responses that can be attributed to different concepts of talent definition. The numbers assigned to more general definitions are the sum of responses corresponding to detailed definitions.

Comparing the results described in Figure 3 with answers to the next question about competences, which should distinguish people recognized as talents, the conclusion was drawn that for the vast majority of respondents talent is a person who, due to their competences or potential for their development, is particularly important for the organization and is distinguished primarily by the desire for self-development, proactivity and problem-solving skills. It may be interesting to note that for women, "ease of adjustment to change" and "efficient learning" turned out to be more important, and for men "problem-solving skills" and "high scores in previous work". One of the key information about the role of talent management in the employee retention process is the fact that $86 \%$ of respondents indicated that in their opinion they should be defined as "talent" in their organization. This means most likely that in their opinion they meet the above-mentioned definition criteria of talent. These premises lead to the conclusion that SSC employees are largely interested at the level of the declaration to improve their competences and stay in the organization that will enable them to do so. 


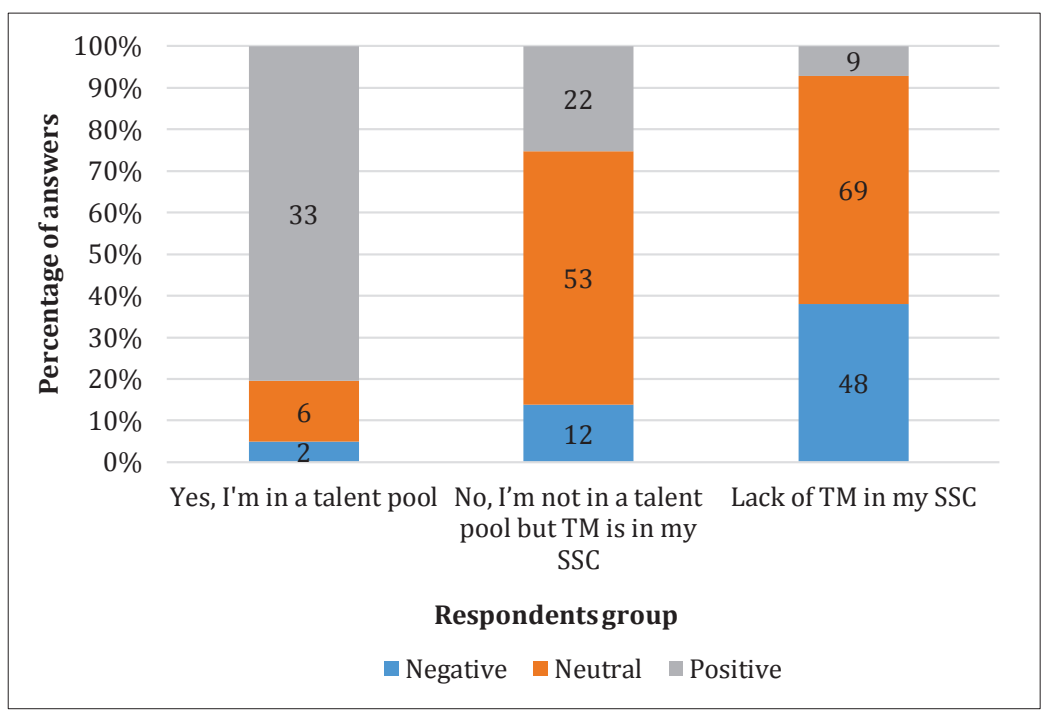

Figure 2. Emotions related to talent management

Source: own study based on research results.

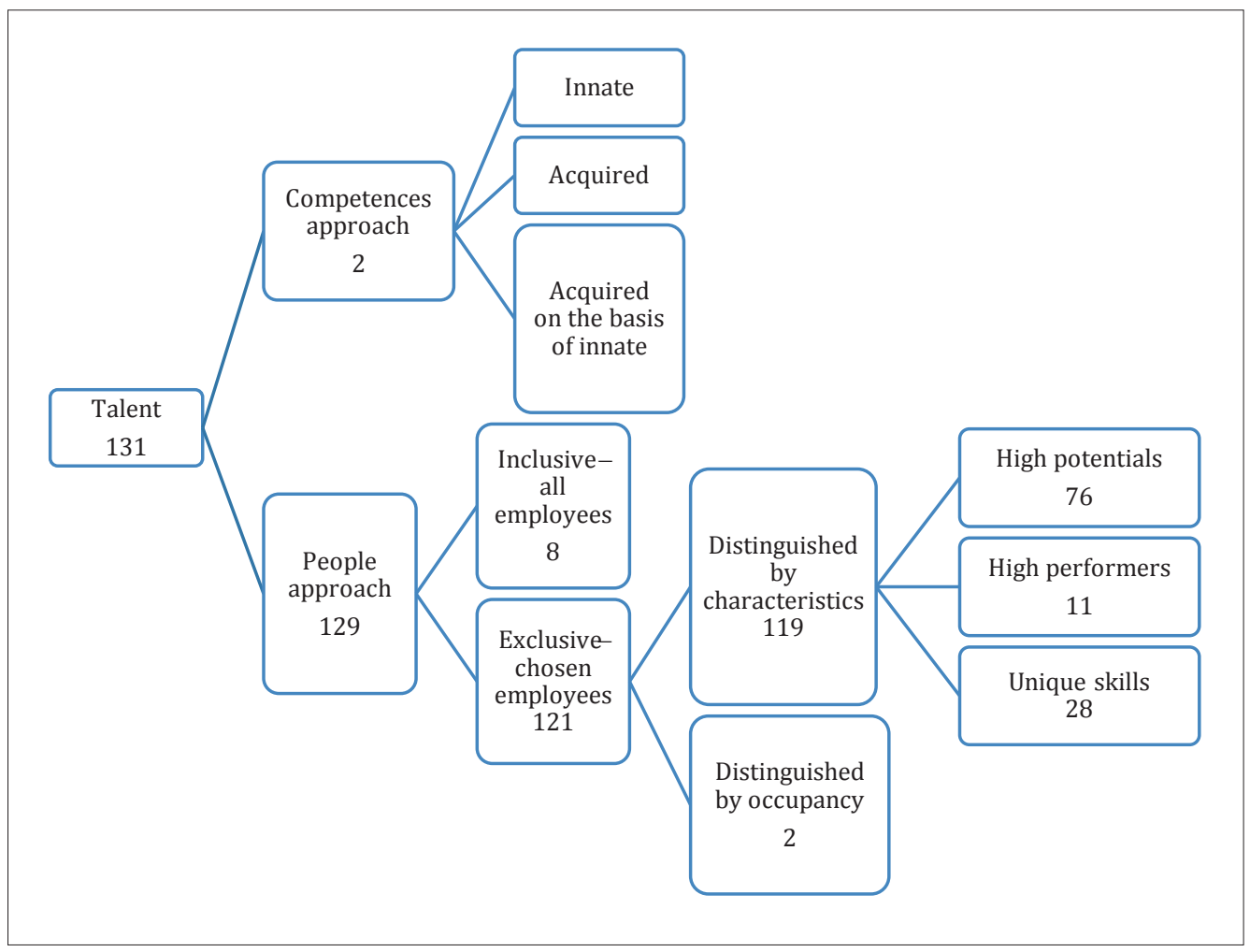

Figure 3. Types of the definition of the concept of talent in respondent's organizations.

Source: own study based on research results.

\subsection{Actions supporting employee retention}

The activities that affect the employee's maintenance in the SSC were decided to be verified with the help of two questions. First, regarding reasons that could affect the willingness to stay in the organization for more than 2 years and second, addressing the reasons why the employee may make a decision to resign from work.
As expected, the intention to stay at work is primarily influenced by three factors:

1) friendly work atmosphere,

2) above average remuneration,

3) clearly defined development perspectives.

The remaining answers, with the exception of social projects implemented by the organization (CSR), also received a high 
number of responses. Statistically significant differences with respect to descriptive variables were:

1) Managerial competences of superiors were important especially for people in the position of a leader and manager $\left(\chi^{2}=10.306, p\right.$-value $\left.=0.01613\right)$.

2) The possibility of implementing projects of strategic importance was all the more important the higher the place occupied by the employee $\left(\chi^{2}=33.1, p\right.$-value $\left.=3.067 \mathrm{e}-07\right)$.

3) Flexible working time was important for people with professional experience below 2 years in a given SSC and significantly less important for people working shorter hours $\left(\chi^{2}=6.8053, p\right.$-value $\left.=0.009089\right)$.

4) Flexible working time was also very important in medium and large enterprises and less important (though important) in enterprises employing more than 100 people $\left(\chi^{2}=10.983, p\right.$-value $\left.=0.01182\right)$.

5) Above-average remuneration was much more important for people aged 20-30 than people aged above 30 and above $40\left(\chi^{2}=8.987, p\right.$-value $\left.=0.002719\right)$.

When verifying the factors affecting the resignation from work, it was shown that the most important were the limited development opportunities and lack of appreciation, and only in the third place higher remuneration in another place of work. Statistically significant differences occurred in particular in the scope of:

1) For people working over 2 years, a significant reason for leaving were conflicts with superiors - twice as much as in the case of people who worked for 2 years or less $\left(\chi^{2}=\right.$ 5.4586 , $\mathrm{p}$-value $=0.01947$ ).

2) Lack of a sense of appreciation was one of the two most important reasons for leaving the organization, but it was even more important when the respondent worked in a larger organization $\left(\chi^{2}=9.7957\right.$, $p$-value $=0.02039$ ).

3) Working with incompetent employees was quite important, especially for employees of CUW employing less than 100 people $\left(\chi^{2}=8.9628\right.$, $p$-value $\left.=0.02979\right)$.

4) Higher remuneration in another workplace was a motivating factor for changing the workplace for younger employees- and to a small extent affecting employees below 30 years of age. $\left(\chi^{2}=6.0791\right.$, $p$-value $\left.=0.01368\right)$.

5) Higher remuneration was also a more important factor motivating men to change their place of work than women $\left(\chi^{2}=4.4984\right.$, -value $\left.=0.03393\right)$.

\section{Conclusions}

This study shows that similar but not the same factors affect employees motivation to stay in the organization and their motivation to leave it. Talent management may have a positive effect on retaining SSC employees if it:

1) triggers a sense of appreciation for employees,

2) creates opportunities for open membership in a group,

3) has precisely defined inclusion criteria,

4) provides the opportunity to maintain a friendly atmosphere with existing colleagues and in the new environment (other talents, project team, etc.),
5) involves working with a supervisor or mentor in a studentmaster relationship,

6) clearly defines development perspectives and indicates a kind of competences and a way they should be developed,

7) takes the responsibility for the development of their own competences,

8) monitors the current workload of talents and combines them with a potential change in the hierarchy of values, eg. in terms of the work-life balance concept,

9) provides opportunities for obtaining additional financial or non-financial remuneration. In particular, the second form should be considered when presenting talent for the benefits of joining talent activities,

10) enables people to work throughout the organization to determine in which areas they feel strong and encourage them to use these competences to transform their organization into shared services centers of the second generation.

Meeting these criteria also seems to respond to the expectations of the respondents regarding the entire functioning of the organization. In this context, the discussed concept of talent management may have a positive impact on employee retention. Such conclusions were reached after analyzing how talent management was perceived by current employees of shared service centers and how it could be used to fit their expectations.

\section{References}

ABSL, 2017a, Business Services Sector in Poland 2017, https://www. everestgrp.com/wp-content/uploads/2017/07/Business-Services-Sector-in-Poland-ABSL-2017-min.pdf, access date 01.2019.

ABSL, 2017b, Business Services in Poznań, https://absl.pl/wp-content/ uploads/2017/01/raport_poznan_EN_180802_epub.pdf, access date 01.2019

Almaaitah M.F., Harada Y., Bin M.F., 2015, Core Principles for Talent Management System and its Impact on Competitive Advantage " Applied Study Cellular Communications Companies in Jordan, International Journal of Academic Research in Business and Social Sciences, June, Vol. 5, no. 6, pp. 298-310.

Altınöz M., Çakıroğlu D., Çöp S., 2013, Effects of Talent Management on Organizational Trust: A Field Study, Procedia-Social and Behavioral Sciences, no 99, pp. 843-851.

CIPD, 2009, Annual Survey Report 2009: Learning and Development, https://www.cipd.co.uk/Images/annual-review_2009-10_tcm 18-11766.pdf, access date 01.2019.

CIPD, 2011, Annual Survey Report 2011: Learning and Talent Development, Action Learning Research and Practice, https://www.cipd. co.uk/Images/annual-review_2011-12_tcm18-11768.pdf, access date 01.2019

CIPD, 2013, Annual Survey Report 2013: Learning and Talent Development, p. 46, https://www.cipd.co.uk/Images/resourcing-and-talent-planning_2013_tcm18-11302.PDF access date 01.2019

CIPD, 2014, Annual Survey Report 2014: Learning and Development, https://intelligentne.ee/wp-content/uploads/2016/02/CIPD-2014-RAPORT.pdf, access date 01.2019

CIPD, 2015, Annual Survey Report 2015: Learning and Development, https://www.cipd.co.uk/Images/learning-development_2015_ tcm18-11298.pdf, access date 01.2019. 
Collings D., Scullion H., Vaiman V., 2015, Talent management: Progress and prospects, Human Resource Management Review, April, no. 25(3), pp. 233-235.

Dąbrowski J., 2016, Rozwój talentów w centrach usług wspólnych, Kwartalnik Prawo-Społeczeństwo-Ekonomia, no. 1, pp. 1-15.

Dąbrowski J., Skowron-Mielnik B., 2016, Kompetencje wyróżniające pracowników określanych jako talenty, Praca Naukowe Uniwersytetu Ekonomicznego we Wrocławiu, no. 430.

Ernst \& Young, 2013, Shared services optimisation. Elevation to the next generation of shared services, https://www.scribd.com/document/337271244/Shared-services-optimisation-pdf, access date 01.2019 .

Gallardo-Gallardo E., Thunnissen M., Scullion H., 2017, Special issue of International Journal of Human Resource Management. A contextualized approach to Talent Management: Advancing the field, The International Journal of Human Resource Management, no. February, pp. 1-4.

Howe M., Davidson J., Sloboda J., 1998, Innate talents: reality or myth, Behavioural and Brain Sciences, no. 21(3), pp. 399-442.

Ingram T., 2016, Zarządzanie talentami w kulturze i sztuce, Studia Ekonomiczne, Vol. 256.

Ingram T., Glod W., 2016, Talent management in healthcare organizations - qualitative research results, Procedia Economics and Finance, no. 39, pp. 339-346.

Joyce W.F., Slocum J.W., 2012, Top management talent, strategic capabilities, and firm performance, Organizational Dynamics, no. 3, pp. 183-193.

Kim S., Mclean G., 2012, Global talent management: necessity, challenges, and the roles of HRD, Advances in Developing Human Resources, no. 14(4)

Kohtamäki M., Kraus S., Mäkelä M., Rönkkö M., 2012, The role of personnel commitment to strategy implementation and organisational learning within the relationship between strategic planning and company performance, International Journal of Entrepreneurial Behaviour \& Research, no. 2, pp. 159-178.

Lepori B., Seeber M., Bonaccorsi A., 2015, Competition for talent: Country and organizational-level effects in the internationalization of European Higher Education Institutions, Research Policy, no. 44(3), pp. 789-802.

Lewis R., Heckman R., 2006, Talent Management: A Critical Review, Human Resource Management Review no. 16, p. 139.
McDonnell A., Collings D., Mellahi K., Schuler R., 2017, Talent management: a systematic review and future prospects, European Journal International Management, no. (11)1, pp. 86-128.

Muntean S.N., 2014, Talent management and its contributions to the performance of the multinational organizations, Revista Academiei Fortelor Terestre, no. 3, pp. 300-306.

O'Connor M., Mangan J., Cullen J., 2006, Management development in Ireland: justifying the investment, Journal of Management Development, no. 4 , pp. 325-349.

Ready D.A., Hill L.A., Conger J.A., 2008, Winning the Race for Talents in Emerging Markets. Harvard Business Review, December.

Schulz V., Brenner W., 2010, Characteristics of shared service centers, Transforming Government: People, Process and Policy, no. 3, pp. 210-219.

Singh A., Sharma J., 2015, Strategies for talent management: a study of select organizations in the UAE, International Journal of Organizational Analysis, no. 23(3), pp. 337-347.

Skowron-Mielnik B., 2012, Założenia modelowania elastycznej organizacji pracy, [in:] Listwan T., Stor M. (eds.), Sukces w zarzq̨dzaniu kadrami. Elastyczność w zarzq̨dzaniu kapitałem ludzkim, Wydawnictwo Uniwersytetu Ekonomicznego we Wrocławiu, Wrocław.

Solberg H.A., 2015, Talent development in football : are young talents given time to blossom?, Sport, Business and Management: An International Journal, no. 5(5), October.

Sparrow P., Makram H., 2015, What is the value of talent management? Building value-driven processes within a talent management architecture, Human Resource Management Review, no. 3, pp. 249-263.

Szulaski S., 2012, Procesowe i organizacyjne innowacje $w$ centrach usług wspólnych, Acta Universitatis Lodziensis, no. 268.

Tansley C., Harris L., Stewart K., Turner P., Foster C., Williams H., 2006, Talent Management: Understanding the Dimensions Change Agen$d a$, Nottingham Trent University, CIPD, London.

Thunnissen M., Van Arensbergen P., 2015, A multi-dimensional approach to talent, Personnel Review, no. 44(2), pp. 182-199.

Valverde M., Scullion H., Ryan G., 2013, Talent management in Spanish medium-sized organisations, The International Journal of Human Resource Management, Vol. 24. 